\title{
Sustainable Agricultural Development in India with Special Reference to Jammu and Kashmir: A Macro Analysis
}

\author{
Waseem Hassan Khan ${ }^{1}$, Aamir Jamal ${ }^{2}$ and Ashiq Hussain $\mathrm{Shah}^{3}$ \\ ${ }^{1}$ Research Scholar, Department of Economics, Central University of Jammu, Jammu \& Kashmir, India \\ ${ }^{2}$ Research Scholar, Department of Economics, Central University of Kashmir, Jammu \& Kashmir, India \\ ${ }^{3}$ Economics Lecturer, DPS, Srinagar, Jammu \& Kashmir, India \\ E-Mail: waseemkhan160@gmail.com, aamirjama106@gmail.com,shahashiqhussain2@gmail.com
}

\begin{abstract}
The new agenda in Indian agriculture should have a goal that explicitly focuses on improving agricultural systems and addresses rural development in an integrated manner. While Indian agriculture has crossed the threshold of traditional farming to modern agri-business, the objective of ensuring equity and sustainability becomes all the more important. Agriculture must change to meet the rising demand, to contribute more effectively to the reduction of poverty and malnutrition, and to become ecologically more sustainable. The challenge is daunting but feasible. This paper will analyze the issues and achievements related to sustainable agriculture development especially in the state of $\mathrm{J \& K}$.

Keywords: Agri-Business, Malnutrition, Ecology, Traditional Farming
\end{abstract}

\section{INTRODUCTION}

Agriculture constitutes an important sector of the State economy as around 65 percent of the population of $\mathrm{J} \& \mathrm{~K}$ derives its income directly or indirectly from this sector. Majority of its population revolves around the agriculture allied sectors for their livelihood. The food grain production of India for the year 2010-11 estimated at 24156 thousand tones while in $\mathrm{J} \& \mathrm{~K}$ total food production during the same period was 137.15 thousand tones which reflects the very low share of 0.6 percent ranks 20th in the list of contributing states. The net sown area under agriculture 7.52 lakh hectare in the year 2004-05. Over 70 percent of the net sown area is under food crops and a little over 13 percent is under fruits. For the sustained growth of agriculture in Jammu and Kashmir, the focus should not be only on attaining food and nutritional security but also on the concerns of declining productivity, environmental degradation and ecological unsustainability.

Agricultural policy of the state aims at 4 percent growth with the achievement of sustainability. It is reflected that it deals with two challenges:

1. Increasing Agricultural productivity and profitability to keep a pace of growth with changing demand.

2. Promoting long term sustainability of agricultural production. In order to deal with the challenges, steps can be taken in the form of adoption of HYV seeds, irrigation and intensive use of fertilizer etc. Along with these, in the present time, the importance of sustainable agriculture cannot be denied.
In context of sustainability, whether agriculture will be able to meet future food demand without adversely affecting the resource base. The sustainable agriculture is also essential to provide sufficient food and also act as an engine of poor growth despite resource constraints. The National Policy on Agriculture gives special emphasis for sustainability of Agriculture as : utilization of vast and untapped growth potential of Agriculture; Strengthening the rural infrastructure to support fast agricultural development; Promotion of value addition and to accelerate the growth of agriculture based business; creation of employment in rural areas; Securing fair standard of living for the farmers and agricultural workers including their families; discouraging migration to urban areas; facing the challenges arising out of the Economic Liberalization and Globalization (Takle, 2016).

The economic concerns in the state of $J \& K$, realizing the need of sustainable agriculture, are low crop productivity which reflects in the low average size of holding, here 94 percent of the holding fall in the size of less than 2 hectare and around 81.5 percent is less than 1 hectare. Along with these, the agrarian economy of Jammu and Kashmir has been facing the problem of credit which is required for productive and non- productive business needs of the cultivators. In the year 2011-12, credit supplied in J\&K, the share of public sector banks was 21.82 percent, commercial banks credit was 68.63 percent and rural regional and cooperative banks supplied near about less than 10 percent. Marketing facilities in the state are not satisfactory; no new techniques are used for providing better market facilities to the agricultural produce. Capital inadequacy, lack of infrastructural support and agriculture being carried out as a subsistence option of livelihood have influenced the economic viability of the agriculture sector resulting in new generation of farm youth moving away from agriculture and looking for urban areas (Bandral\& Sharma, 2013)

India has gone through the current structural, institutional and technological reforms for the overall growth of the economy. It is necessary on the part of the government to give due priorities to key segments like marketing, price mechanism, technology, R\&D and trade. Similarly it has been observed that with the support of the government and with private interference, the goal of sustainable agricultural 
can be attained. At the same time, priorities must be given to enhance the overall standard of living of the rural poor so that it would go a long way for eliminating socio-economic constraints like poverty, hunger and malnutrition (Samantaray, 2015). The growth and development in the agriculture is achieved by Green Revolution. It is the need of the hour to maintain the resources and to respond the climate change. The conservation of water resources is required to be focused. To face the difficulties in summer and the decrement in the rain fall, it is important to save a single drop of water, for this one of the strategies that to pour the water collected by the roof in the land, other strategies may be dividing land in to several other parts to match the demand and supply for food grains and the vegetables (Nerker, et al, 2013). From the performance of agricultural sector of India we will easily recognize that performance have been increased in a significant manner over the years. Despite of many challenges like urbanization, growth of secondary sector etc. it has achieved a significant growth (Shukla \& Dwivedi, 2015).

The conditions for development of sustainable agriculture are becoming more and more favorable. New opportunities are opening the eyes of farmers, development workers, researchers and policy makers. They now see the potential and importance of these practices not only for their direct economic interest but also as the basis of further intensification and ecological sustainability. This does not mean that agro-chemicals can be abandoned. Also, research has an important role to play. Bankers and funders should think of how best to provide incentives and credits, accessible to poor farmers and women, to make investment in dry land farming possible. As conditions for farming will continue to change, the key to sustainable agriculture is the capacity of farmers and all other actors in agricultural development, as well as the wider society, to learn, experiment, adapt and cooperate in an effective way. To conclude, a small farm management to improve productivity, profitability and sustainability of the farming system will go a long way to ensure the all-round sustainability (Narayan, 2012).

\section{OBJECTIVES}

1. To highlight potentials, limitations/drawbacks and strategies for the sustainable development of agriculture sector in $\mathrm{J} \& \mathrm{~K}$.

2. To study recent achievements in terms of Seed Replacement Rate (SRR) in the state of J\&K.

3. To study financial achievements of various Centrally Sponsored Schemes implemented for the welfare of farmers and sustainable growth in agricultural sector of $\mathrm{J} \& \mathrm{~K}$.

\section{METHODOLOGY}

This study is based on the secondary data. The data collected from different sources especially from J\&K Annual Economic Surveys for the years from 2014-17.
Besides this, data is also collected from other different reliable sources like articles, reports, journals etc.

\section{DISCUSSION}

The Agriculture Sector in J\&K faces many problems such as low growth, low yields, limited scope of extending cultivativable area, land degradation, hilly terrain, small and fragmented land holdings and so on. Meanwhile, potentials, limitations and strategy related issues are given as under:

\section{A. Potentials}

1. Organic Basmati Rice, Rajmash, off-season vegetables, potatoes, aromatic \& medicinal plants.

2. Virus free potato seeds for all seasons.

3. Development of commercial floriculture, Production of virus free quality seeds for flowers and vegetables, aromatic \& medicinal plants.

4. Mushrooms round the year, honey and honey byproducts, fodder intensification, etc.

5. Wide range of flora available to boost bee keeping.

6. Boost to Quality Saffron Production.

7. Jetropha (Biofuel) cultivation on waste lands and rainfed areas of Jammu region under NWDPRA.

\section{B. Limitations/Drawbacks in Agriculture}

1. Hilly Terrain.

2. Small and fragmented land holdings.

3. Fragile Soil in hilly areas susceptible to soil erosion.

4. Limits to mechanized farming and transportation of products.

5. Extreme limits to irrigation of cultivated land.

6. Single Cropping season in temperate / high altitude areas.

7. Inadequate and unorganized marketing infrastructure.

8. Distant markets for export outside the State.

\section{Strategy}

1. Timely sowing of treated seeds of rice, maize etc.

2. Timely arrangements and easy access of inputs (seeds, fertilizers, technology, etc.)

3. Ensuring supplies of Quality Inputs \& Services, Stress on Soil \& Water Management.

4. Augmenting seed/grain storage capacity of farmers.

5. Gearing up Extension Network \& Capacity building of farmers in quality seed production.

6. Diversification in cropping system to:

a. Reduce pressure on water resources.

b. Provide alternatives for marketable crop products and higher income.

c. Generate more employment opportunities through crops having scope in value addition such as MAPs, Bamboo, Flowers, Fruits, Sericulture, etc.

7. Augmenting credit through KCCs.

8. Intensive and extensive research development in the farm business management must be accelerated. 


\section{Seed Management and Seed Replacement Rate (SRR)}

Seed Replacement Ratio denotes how much of the total cropped area was sown with certified seeds in comparison to farm saved seeds. It also denotes actual quality seed distributed to farmers vis-a-vis actual seed required for cultivation of crops. The national average of seed replacement rate has been above 25 percent while the $J \& K$ State is pursuing its efforts to consistently achieve the desired level of Seed Replacement Rate (SRR) in case of High Yielding Varieties of major crops. The limitation of availability of breeder and foundation seeds is also a contributory factor. The desirable SRR level 25 percent for self pollinated crops, $35 \%$ for cross pollinated crops and 100 percent for hybrids at the national level have now been revised to $50 \%$ for cross pollinated crops and $33 \%$ for self pollinated crops.

TABLE I SEED REPLACEMENT RATE ACHIEVEMENTS IN J\&K (IN \%)

\begin{tabular}{|c|l|c|c|c|c|c|c|c|c|}
\hline \multirow{3}{*}{ Season } & \multirow{2}{*}{ Crop } & $\mathbf{2 0 1 1 - 1 2}$ & $\mathbf{2 0 1 2 - 1 3}$ & $\mathbf{2 0 1 3 - 1 4}$ & \multirow{2}{*}{$\mathbf{2 0 1 4 - 1 5}$} & \multirow{2}{*}{$\mathbf{2 0 1 5 - 1 6}$} & \multicolumn{3}{|c|}{$\mathbf{2 0 1 6 - 1 7}$} \\
\cline { 5 - 10 } & & & & & & & KMR & JMU & Average \\
\hline \multirow{5}{*}{ Kharief } & Paddy & 22.4 & 32.52 & 25 & 29.68 & 32.54 & 33 & 42.59 & 37.795 \\
\cline { 2 - 10 } & Maize & 18.15 & 15.48 & 16.22 & 28.05 & 29.69 & 30 & 40.90 & 35.45 \\
\cline { 2 - 10 } & Pulses & 42.89 & 35 & 35 & 20.87 & 70.38 & 47 & 8.33 & 27.66 \\
\cline { 2 - 10 } & Fodder & 15.18 & 55 & 55 & 59.98 & 61.00 & 45 & 69.56 & 57.28 \\
\hline \multirow{3}{*}{ Rabi } & Wheat & 26.05 & 27.34 & 32.19 & 40.25 & 41.84 & 45 & 33.80 & 39.40 \\
\cline { 2 - 10 } & Pulses & 9.21 & 17.53 & 17.53 & 3.63 & 2.56 & 41 & 8.33 & 24.665 \\
\cline { 2 - 10 } & Oilseeds & 41.87 & 40.46 & 31.7 & 33.60 & 39.28 & 46 & 64.13 & 55.065 \\
\cline { 2 - 10 } & Fodder & 26.89 & 24.82 & 25 & 32.23 & 28.75 & 41 & 82.73 & 61.865 \\
\hline
\end{tabular}

Department of Agriculture has registered a $33 \%$ SRR of rice in Kashmir valley and 42.59 in Jammu Division. SRR in respect of maize was observed $30 \%$ in Kashmir and $40.90 \%$ in Jammu Division. SRR in respect of Fodder is anticipated at $45 \%$ and $69.56 \%$ during Kharief Season in Kashmir and Jammu respectively during 2016-17 (J\&K Economic Survey, 2014-17). The SSR in respect of Rabi season for both the divisions is also reflected in the above Table I.

\section{E. Centrally Sponsored Schemes}

Various Centrally Sponsored Schemes are being implemented for the welfare of the farmers and growth in the Agriculture Sector:

\section{Rashtriya Krishi Vikas Yojana}

The scheme aims to achieve the goal of reducing the yield gaps in important crops, through focused interventions \& good productive practices, to maximize returns to the farmers in Agriculture \& allied sectors and bring quantifiable changes in the production \& productivity of various components of Agriculture \& allied sectors by addressing them in a holistic manner. The financial targets $\&$ achievements registered during 2016-17 is as under.

During 2016-17, the department had an unspent balance of Rs 1160.44 lakh against which Rs 848.02 lakh has been revalidated and the expenditure was of Rs 588.163 lakh. In addition, during 2016-17 department had a provision of Rs. 9323.00 lakh for the implementation of the Rashtriya Krishi Vikas Youjna (RKVY) (Rs. 3973.00 lakh RKVY Normal,
Rs. 5000.00 lakh under National Mission on Saffron and Rs 350.00 lakh under Foot and Mouth Disease). Against this an amount of Rs. 4972.48 lakh was released (Rs. 3849.00 lakh Central Share and Rs. 1123.48 lakh as State Share).

\section{National Mission for Sustainable Agriculture}

National Mission for Sustainable Agriculture proposes to achieve various objectives to make agriculture more productive, sustainable remunerative and climate resilient by promoting location specific Integrated/Composite Farming Systems, to conserve natural resources through appropriate soil \& moisture conservation measures, to adopt comprehensive soil health management practices based on soil fertility maps, soil test based application of macro \& micro nutrients, judicious use of fertilizers etc, to optimize utilization of water resources through efficient water management to expand coverage for achieving more crop per drop, to develop capacity of farmers \& stakeholders, in conjunction with other ongoing Missions and to establish an effective inter and intra Departmental/Ministerial coordination for accomplishing key deliverables of National Mission for Sustainable agriculture under the aegis of NAPCC. The CSS NMSA after restructuring is to be implemented under the following heads of development
a. Rainfed Area Development Programme (RADP).
b. Climate Change \& Sustainable Agriculture Monitoring, Modeling \& Networking.
c. Soil Health Mission (SHM).
d. Paramparagath Krishi Vikas Yojana (PKVY).

An amount of Rs. 153.65 lakh was available under Rainfed Area Development during 2016-17 which includes Rs. 
142.55 lakh unspent balance and Rs. 11.10 lakh as State Share. Against which 96.30 lakh has been utilized during the year. For the Climate Change Intervention, one block each in District Budgam/ Jammu is being covered under Climate Change. Proposal on pilot basis to introduce climate resilient varieties of seeds etc to check the adverse effects of climate on production. An amount of Rs. 103.94 lakh was available during 2016-17 under Soil Health Management which includes Rs. 25.31 lakh of unspent balance and Rs. 78.63 lakh as State Share. Against which 45.91 lakh has been utilized during the year. An amount of Rs. 79.85 lakh was available under Soil Health Card Scheme which includes Rs. 56.14 lakh of unspent balance and Rs. 23.71 lakh as State Share. Against which the expenditure during 2016-17 was Rs. 50.02 lakh. The achievements made during the year is as under

a. 108690 farmers covered during 2016-17.

b. 139295 soil samples taken.

c. 74565 samples tested.

d. 249920 Soil Health Cards generated/printed during the period.

e. An amount of Rs. 134.87 lakh was available under Paramparagath Krishi Vikas Yojana which includes Rs. 32.96 as un-spent balance, Rs. 87.81 lakh as fresh release and Rs. 14.10 lakh as State Share. Against which the expenditure was Rs. 62.73 lakh.

\section{National Mission on Agricultural Extension and Technology (NMAET)}

The scheme aims to extend Agricultural education for transfer of technology, introduction of improved seeds, limited and specific use of pesticides \& introduction of modern farm business machinery. The scheme envisages implementation of the core components for ensuring easy availability of inputs (i.e. seeds, pesticides \& machinery) at reasonable prices. Agricultural Extension \& Technology have to go hand in hand and that is the genesis of the National Mission on Agricultural Extension \& Technology, so that delivery of appropriate technology \& improved Agronomic Practices are enabled. The CSS NMAET has been restructured $\&$ is comprising of sub-schemes viz, SubMission on Agricultural Mechanization; Sub-Mission on Agricultural Extension; Sub-Mission on Seed \& Planting Material and Sub-Mission on Plant Protection. An amount of Rs 3365.46 lakh has been approved for the implementation of NMAET which includes Sub-Mission on Agriculture Mechanization (Rs. 356.67 lakh), Sub-Mission on Agricultural Extension (Rs. 1507.78 lakh) and SubMission on Seed \& Planting Material (Rs.1501.01 lakh) during 2016-17. An amount of Rs. 1904.77 Lakh (including State Share of Rs. 285.79 lakh) has been received by the Department for the implementation of various programmes in a mission mode manner during the year 2016-17. Besides there was unspent balance of Rs. 316.36 lakh. Therefore the total availability during the year was Rs. 2221.13 lakh. Against which an amount of Rs. 1925.50 (Including Rs.
208.67 lakh as State Share) has been utilized during the year.

\section{National Food Security Mission (NFSM)}

National food Security Mission is under implementation in $\mathrm{J} \& \mathrm{~K}$ to increase the disease free Food production of rice, wheat, pulses \& course cereals (Maize), to increase the farmer's income by making the farm business management more profitable and to generate employability. During 2016-17, action plan has been approved at an amount of Rs. 1584.12 lakh. An amount of Rs 871.26 lakh has been received (Central Share as Rs. 712.85 lakh \& State Share Rs 158.41 lakh) against which Rs.7739.41 lakh has been expended during 2015-16 which includes the state share of Rs 110.548 lakh.

\section{National Mission for Oilseed and Oil Palm (NMOOP)}

Action Plan of Rs. 111.87 lakh was approved for the year 2016-17. No Central Share was released during the year. However there was an unspent amount of Rs. 38.82 lakh against which Rs. 27.09 lakh were utilized during 2016-17. Moreover against State Share of Rs. 11.19 lakh available during 2016-17, Rs. 3.61 lakh were expended. Under Mini Mission Ist (MM-I), 26 was brought under rape seed and mustard block demonstration crop/variety-wise by way of providing of $50 \%$ of the cost of inputs on rape seed and mustard besides one farmers training programme was also organized.

\section{Pradhan Mantri Fasal Bima Yojana (PMFBY)}

The scheme provides uniform premium as only $2 \%$ to be paid by the farmers for all Kharif crops, $1.5 \%$ for all Rabi crops and in case of annual commercial and horticulture crops the premium is $5 \%$ only of sum insured.

\section{Pradhan Mantri Krishi Sinchaye Youjna (PMKSY)}

The scheme is for a period of five years from 2015-2020 to achieve "more crop per drop" for overall rural prosperity. The funding for the works proposed under comprehensive water security plan is to be obtained through convergence from existing centrally sponsored schemes e.g. MNREGA, PMKSY, IWMP etc. As about 75 percent of the net cultivated area of Jammu region and 60 percent of Kashmir region is un-irrigated. The Department has drawn up 22 District Irrigation Plans (DIPs) requiring Rs. 14688.46 crore to be executed in a phased manner to make efficient and judicious use of every drop of irrigation water under the Pradhan Mantri Krishi Sinchai Yojana (PMKSY).

\section{Command Area Development \& Water Management Programmes}

The following projects of Command Area Development are under execution/ are being taken up: 
a. In Kashmir Division 09 projects of CAD are of ongoing nature at Ahaji, Bheerwa, Kehmil, Kupwara, Ferozpora, Tangmerg, Sonawari, Ganderbal, Uri, Tongri, Shopian, Waishow, Kulgam \& Kargil.

b. Four projects have been completed and five (05) are of ongoing nature.

c. 12 new projects at Arapath, Rambaria Romshi, Devsar, Lar, Shukhanag, Nigli, Amragad, Shali Ganga \& Dood Ganga, Puhroo Kupwara, Sind Valley, Shahoora, Tral, Gurez, Rafiabad was proposed during financial year 2016-17.

d. In Jammu Division Ranbir canal CAD Project has been completed.

e. New Partap canal CAD project is ongoing project expected to be completed during the financial year 2016-17.

f. Five new projects at PargwalUdhampur, Rajori, Kishtwar\&Ramban have been approved by the Ministry of Water Resources GoI and are under execution during financial year 2016-17.

g. All the above projects are part of Prime Minister's Krishi Sinchayee Yojana.

\section{CONCLUSION}

From the above discussion, it is concluded that there are various limitations in agricultural sector of $\mathrm{J} \& \mathrm{~K}$ state. It is due to its geographics, limited irrigation, marketing and transportation problem. But, there is a potential for sustainable agricultural development as the State has rich flora and fauna, vegetable cultivation, rice, aromatic and medicinal plants cultivation potential, potential of bio-fuel plant cultivation, quality saffron production. In order to harness this potential, there are strategies to be followed for sustainable agricultural development. One of the important strategies is seed management and seed replacement, which is being followed in J\&K. From the discussion, it can be concluded that on an average the J\&K department of agriculture has registered Seed Management \& Seed Repalcement Rate (SRR) of about $40 \%$ for kharief crops and $45 \%$ for rabi crops. Further, from the study, it is revealed that the financial performance of various centrally sponsored schemes launched for sustainable agricultural development has improved over the past few years in J\&K.

\section{REFERENCES}

[1] Bandral, N., \& Sharma, K. Towards a Sustainable Agriculture: Special Reference to Jammu and Kashmir. Agriculture: Towards a New Paradigm of Sustainability, 142-145.

[2] Gupta, A.K. (1990). Sustainable Development Of Indian Agriculture: Green Revolution Revisited. IIM, Ahmedabad.

[3] Narayan, S. B. (2012). Sustainable Agricultural Development and Organic Farming In India. Golden Research Thoughts, 1(11), 1-4.

[4] Nerker, K.R., Kale, V.S. \&Bhadale, R. (2013). The Sustainable Growth and Development of Indian Agriculture. Asia Pacific Journal of Marketing \& Management Review, 2(6), 117-119.

[5] Samantaray, L.L. (2015). A Study on the Current Trend of Agricultural Productivity in India and its Future Prospects. International Journal of Humanities Social Sciences and Education, 2(4), 16-21

[6] Shukla, H.K. \&Dwivedi, N.U. (2015). Sustainable development in agricultural sector in India. The Business \& Management Review, 5(4), 220-222.

[7] Takle. S.R. (2016). Sustainable Agricultural Development in India. Agricultural Science Research Journal, 6(11), 281-286.

[8] Reports \& Surveys: Annual Economic Survey J\&K (2014-17). Directorate of Economics and Statistics, Department, Government of $J \& K$.

[9] Digest of Statistics (2015-16). Directorate of Economics and Statistics, Department, Government of $J \& K$. 